\title{
Effects of artificial diets with different carotene content on the organoleptic characteristics of the gonads and reproductive condition of Loxechinus albus (Echinodermata: Echinoidea)
}

\author{
Cintia Fraysse ${ }^{1}$, Gabriela Malanga ${ }^{2}$ \& Analía F. Pérez ${ }^{1}$ \\ 1. Laboratorio de Invertebrados Marinos. CEBBAD. Universidad Maimónides, CABA, Buenos Aires, Argentina- \\ CONICET; cyn.fraysse@gmail.com; analiafperez1@gmail.com \\ 2. Fisicoquímica IBIMOL, Facultad de Farmacia y Bioquímica, Universidad de Buenos Aires. Junín 954, Ciudad \\ Autónoma de Buenos Aires, Argentina; gmalanga@ffyb.uba.ar
}

Received 08-VIII-2016. Corrected 04-VII-2017. Accepted 12-VIII-2017.

\begin{abstract}
The organoleptic characteristics of sea urchins gonads (size and color, among others) can be improved by artificial diets. Loxechinus albus is considered one of the most economically significant resources from the littoral-benthic systems in the South Pacific Ocean from Peru to Chile. The objective was to determine artificial diets effects on the organoleptic traits of gonads, reproductive condition, body growth and survival of Loxechinus albus. Two types of diets were administrated (low carotene content diet (LC): balanced food with $0.02 \% \beta$-carotene and high carotene content diet (HC): balanced food with $0.045 \% \beta$-carotene) for 16 weeks. As a measurement of growth rate, test diameter of sea urchins fed with artificial diets was measured at the beginning and at the end of the experiment. At both times, size (GI) and color (CI) of the gonads were recorded in ten individuals from each treatment and ten from the natural population (NP). Energy density (ED), energy content (EC) and total carotenes (TCC) were determined by calorimetry and spectrophotometry, respectively. Histological sections were examined microscopically and the sex was identified. Each female was assigned to a gametogenic stage (reproductive condition) and determined: number and diameter of the oocytes, gonadal area occupied by oocytes, and relative frequencies of reproductive stages. At the end of the experiment in relation to the NP, it was possible to achieve higher GI values for both artificial diets. The NP showed higher gonadal area occupied by oocytes and larger oocyte diameter at 16 weeks $(\mathrm{P}<0.01)$. In addition, individuals fed with both artificial diets, presented "growth" and "advanced growth" gonad stages (both times), while the NP individuals, presented stages of "prematurity", "maturity" and "partial spawning" at week 16. The data shows the highest $\mathrm{CI}$ value for the $\mathrm{HC}$ diet at eight weeks $(\mathrm{P}<0.01)$. Moreover, TCC values for the NP were significantly higher at week $16(\mathrm{P}<0.01)$. Loxechinus albus is an appropriate species to be kept in captivity, as their mortality is very low, facilitating the achievement of long-term experiences of gonadal improvement. According to our data the optimal time to improve the organoleptic characteristics is eight weeks with a high carotene artificial diet, since optimal gonad coloration was reached, and GI values did not differ significantly from the ones achieved at the end of the experiment for both diets, or the ones shown in the NP. This is translated into a lower cost by a reduced cultivation time. Rev. Biol. Trop. 65(Suppl. 1): S207-S220. Epub 2017 November 01.
\end{abstract}

Key words: Echinoculture; $\beta$-carotene; gonad histology; gonad improvement; Beagle Channel.

The development of many of the world sea urchin fisheries has been in response to changing economics and sea urchin stock declines in other countries (Andrew et al., 2002). Declining populations of sea urchin and the present demand for theirs gonads have created opportunities for echinoculture (Pearce, Daggett, \& Robinson, 2004).
It is known the regular echinoids ability to compensate for environmental changes with diverse phenotypic responses. For instance, the ability to modify the size and proportion of its body components in response to environmental variations (Russell, 1998; Brady \& Scheibling, 2006). Several field and laboratory studies with echinoderms have concluded that qualitative 
and quantitative changes in the food influence the allocation of resources to individuals' somatic growth and reproduction (Beddingfield \& McClintock, 1998; Guillou, Lumingas, \& Michel, 2000; Pérez, Morriconi, Boy, \& Calvo, 2008). Moreover, the resources allocation is also determined by individual's age, strongly related with the size. For example, small Strongylocentrotus intermedius utilize different food sources from large ones, and relatively more energy is used in small animals for body growth and less for gonadal growth than in larger animals (Fuji, 1967). Most sea urchin species such as $S$. intermedius, $S$. franciscanus and Paracentrotus lividus are characterized by a nonlinear growth pattern with an asymptotic or sigmoidal shape, (Flores, Ernst, \& Parma, 2010) as well as L. albus growth rate that was suggested to fit the von Bertalanffy model (Schuhbauer, Brickle, \& Arkhipkin, 2010).

Carotenoids have an important biological role in growth, survival and reproductive cycles (Borisovets, Zadorozhny, Kalinini, Lepskaya, \& Yakush, 2002). Particularly, dietary carotenoids are considered essential in sea urchin aquaculture because of their effect on gonad color (Plank, Lawrence, Lawrence, \& Olvera, 2002), which is a relevant commercial trait. The optimal color is bright yellow-orange (McBride, 2004). Gonad color can be related to the reproductive condition in some sea urchins; mature gonads show brighter color while recovering, growing or premature stages show less desirable color (Pérez, Malanga, \& Puntarulo, 2011). Furthermore, palatability can be associated with color; bright yellow gonads are sour and those with a slight greenish are bitter (McBride, 2004).

Variations in food supplies can affect reproduction (gametogenesis, maturation, size and number of eggs) even if reproduction may be protected by redirecting resources at the expense of somatic growth (Fernandez \& Boudouresque, 2000). Growth and reproductive capacity are direct functions of diet (Foster, Byrnes, \& Reed, 2015). Gonad relative sizes from different sea urchin species vary with different supplied diets (Lawrence,
1997; Russell, 1998; Pearce et al., 2004; Siikavuopio, Mortensen, Dale, \& Foss, 2007; Foster et al., 2015).

It has been observed that gametogenesis is affected and even stopped, in low food availability (Russell, 1998). Moreover, there have been variations in the size of the oocytes and abundance of nutritive phagocytes after administration of different diets (Garrido \& Barber, 2001). This is to be considered in echinoculture as the reproductive state of the gonads has to remain in early stages to be fleshy and firm without an abundance of gametes spilling when they are consumed (Spirlet, Grosjean, \& Jangoux, 2000). Texture of sea urchin gonads is generally associated with appearance, where the tactile response to texture is important in the overall enjoyment and acceptability. The reproductive condition may give some insight into the structural quality of sea urchin gonads (McBride, 2004).

Loxechinus albus (Molina, 1972) is a sea urchin species with a wide geographic distribution, from Peru (Isla Lobos de Afuera, $\left.6^{\circ} 53^{\prime} 50^{\prime \prime} \mathrm{S}\right)$ to the Chilean southern extreme (Cabo de Hornos, 55 52"S) and Tierra del Fuego $\left(54^{\circ} \mathrm{S}\right)$ (Guisado \& Castilla, 1987). It is considered as one of the most economically significant resources from the littoral-benthic systems in the South Pacific Ocean from Peru to Chile. Natural stocks on Chilean coasts were reduced or depleted due to excessive harvest for commercial purposes. This situation provides opportunities for sea urchin aquaculture and roe enhancement. High gonadal production by feeding with artificial diets has been reported for L. albus by Pérez, Boy, Morriconi, and Calvo (2009) and Pérez, Lattuca, Fraysse, and Malanga (2015), among others.

The objective was to determine the effects of artificial diets enriched with $\beta$-carotene on the organoleptic traits of gonads, reproductive condition, body growth and survival of Loxechinus albus. We propose that it is possible to enhance gonad organoleptic traits and the prolongation of the harvesting season, through a delay in the onset of spawning. To test this first hypothesis, we study the effects of dietary 
carotenoids on the gonad index, gonad color, total carotene content, calorimetric determinations (energy density and energy content) in the gonads, body growth and survival. To evaluate the prolongation of the harvesting season, we perform histological analyses consisting on studying oocyte number, diameter, and size distribution as well as the frequency of gonadal stages on females of L. albus.

\section{MATERIALS AND METHODS}

Study site and sampling: The sampling was performed in 2006, from April to August when gametogenesis develops, until sexual maturity is reached. On April, 40 adult specimens of Loxechinus albus from approximately $70 \mathrm{~mm}$ (minimal legal size for fisheries) (Olave \& Busto, 2001), were collected by SCUBA diving on the Bridges Islands, Beagle Channel (54 $52 \mathrm{~S}$ and $68^{\circ} 11 \mathrm{~W}$; Fig. 1 ).
To standardize nutritional condition among individuals, sea urchins were not fed for 20 days before the beginning of the experiment. These individuals were randomly assigned to one of two experimental groups (each group $n=20$ ). Subsequently, each group was randomly assigned one of the diets: low carotenes (LC) or high carotenes (HC) (Pérez et al., 2015). Both treatments LC and $\mathrm{HC}$ consisted on artificial balanced food with $0.02 \%$ and $0.045 \%$ $\beta$-carotene, respectively. Within each treatment, 20 replicates were established with one individual each. Each individual was placed in an aquarium with and independent system of water and aeration. Aquariums were designed and built by a technician from Ecology, Physiology and Evolution of Aquatic Organisms Laboratory, CADIC (Centro Austral de Investigaciones Científicas). This aquariums consisted of cylinders $30 \mathrm{~cm}$ high and 19 $\mathrm{cm}$ diameter, with a conical bottom, ending

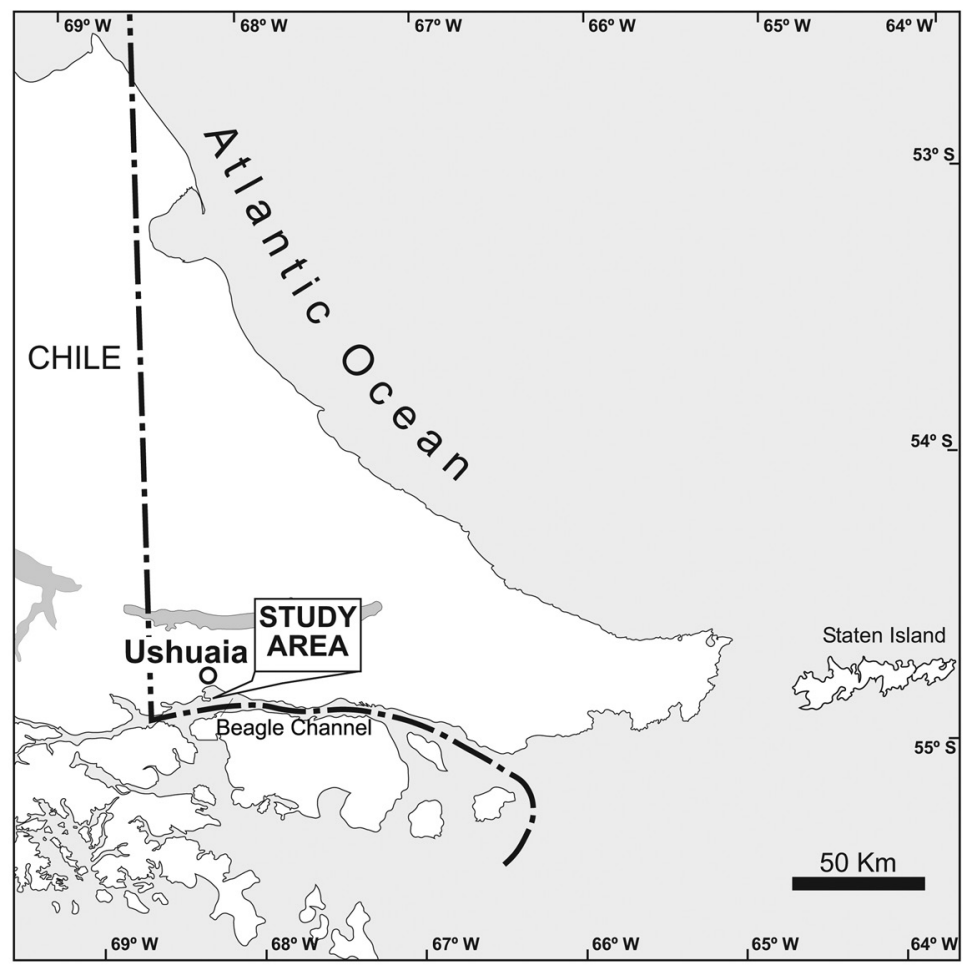

Fig. 1. Sampling area in Bridges Islands, Beagle Channel, Tierra del Fuego, Argentina.

Fig. 1. Área de muestreo en las Islas Bridges, Canal Beagle, Tierra del fuego, Argentina. 
in a latex hose. A horizontal plastic mesh at the beginning of the conical section prevented the passage of food and allowed the concentration of feces. Individuals were fed three times a week, placing a piece a pellet over their test. Concentration of nitrates, nitrites, and $\mathrm{PH}$ was controlled to assure water quality. Moreover, water was changed three times a week before they were fed, using a siphon to extract feces at the bottom of the plastic tanks. Aquariums were kept in conditioned chambers were temperature was $8{ }^{\circ} \mathrm{C}\left( \pm 0.5^{\circ} \mathrm{C}\right)$ and photoperiod, 12 hours of light.

Completed eight and 16 weeks of the experiment, ten individuals of each treatment were sacrificed. At the same time ten individuals of the sampling area were collected and also sacrificed, in order to determine the gonads organoleptic conditions of the natural population (NP). All individuals were anesthetized by immersion in MS-222 (Cossi, Boy, Giménez, \& Pérez, 2015) to ameliorate animal suffering.

Gonad and color indexes, histological analyses, total carotene content and calorimetric determinations were calculated for $\mathrm{LC}$ and $\mathrm{HC}$ diets and NP for each time.

Survival and growth rate: The survival expressed as percentage was calculated as: [Individuals alive at the end of the experiment]/ [number of individuals at the beginning of the experiment]*100 for each treatment. Also, test diameter of sea urchins fed with both artificial diets was measured when captured and at the end of the experiment. So growth rate was calculated as: [test diameter at the end of the experiment ( $\mathrm{mm})$-test diameter at the beginning of the experiment $(\mathrm{mm}) /$ time of experimentation].

Gonad index: Gonads were dissected, weighted $( \pm 0.01 \mathrm{~g})$ and stored at $-80^{\circ} \mathrm{C}$ for total carotene and calorimetric determinations. The gonadal index (GI), expressed as percentages, was calculated as $\mathrm{GI}=[$ Organ wet weight $(\mathrm{g}) /$ Total wet weight $(\mathrm{g})]^{*} 100$.
Histological analyses: One gonad of each specimen was fixed in Bouin's solution over 12 hours and dehydrated in a graded ethanol series. Tissue was embedded in liquid paraffin (Paraplast ${ }^{\circledR}$ ), sectioned at $5-7 \mu \mathrm{m}$ (microtome Leica RM2125RT) and stained with Groat's haematoxylin and eosine (Pérez et al., 2009). Sections were examined microscopically and sex was identified. Additionally in females, each individual was assigned to a gametogenic stage based on Pérez, Boy, Morriconi, and Calvo (2010) and a quantitative study of oocyte types was added to establish the gonadal stages. Digital images of ovary sections were taken with a digital camera attached to an Olympus BX40 microscope and analyzed using Micrometrics SE Premium 4 software. Three microscopic fields were examined (1009; NA: 0.25; Area: $0.378 \mathrm{~mm}^{2}$ ) per female slide. Oocyte number and oocyte diameter $(\mu \mathrm{m}$, largest axis of oocytes with nucleus) were measured in each slide. Means of oocyte diameter and oocyte number were calculated per field (Cossi et al., 2015). In females, five gonadal stages were determined considering histological observations, frequencies of oocyte sizes and gonadal index: growth $(\mathrm{G})$, advanced growth $(A G)$, premature $(P)$, mature $(M)$ and partially spawned (PS).

Color index: Gonad colors were determined comparing the gonad color in fresh with a chart designed by the Maine Cooperative Extension Service Program and the Maine Department of Marine Resources (http://www. maine.gov/dmr/science-research/species/seaurchin/green_sea_urchin_general_summary. $\mathrm{html}$ ), always assessed under standardized light conditions. To build the color index (CI), these colors were then classified into seven categories where category 7 represents most appreciated gonadal color in the market and category 1, the least appreciated:

7: bright yellow

6: pale yellow or brownish orange 
5: mustard

4: bright orange or mustard

3: brownish orange

2: brownish red or brown

1: dark brown or grey

Total carotene content and calorimetric determinations: For each individual, the total carotene content (TCC) in gonads was determined using the McBeth (1972) method modified by Pérez et al. (2015). Total carotenes present in $100 \mathrm{~g}$ of sample were calculated as Carotenioids $(\mathrm{mg}) / 100 \mathrm{gtissue}=\left[\mathrm{A}^{*} \mathrm{To}\right.$ tal volume of the sample $\left.(\mathrm{ml}) * 10^{3}\right] /[\varepsilon *$ total tissue weight $(\mathrm{g})]$ Where, $\mathrm{A}$ is the absorbance at $\lambda_{\max }$ and $\varepsilon$ is the molar extinction coefficient ( $\varepsilon: 2500)$. Total carotene content was obtained multiplying its concentration by the total gonadal wet weight.

For the calorimetric determinations, the gonads were dried in stove at $70^{\circ} \mathrm{C}$ till constant dry weight was reached. Dry material of each sample was pulverized separately using a manual mortar and pellets ( 0.05 to $0.2 \mathrm{mg}$ ) were made with a Parr 2812 press. Energy density (ED) was determined by complete combustion in a micro calorimetric bomb (Parr 1425) following the methodology of Lucas (1996) with the modifications made by Pérez et al. (2008). Data was converted to kilojoules $(\mathrm{kJ})$ per gram of dry weight from material free of ashes (energy density, ED, kJ/g DWFA), considering that 1 calorie is $0.004186 \mathrm{~kJ}$ (Lucas, 1996). Periodic calibrations of the micro bombs were made with benzoic acid. Total gonadal energy content (EC) was calculated as $\mathrm{EC}(\mathrm{kJ})=\mathrm{ED}(\mathrm{kJ} /$ $\mathrm{g})^{*}$ Gonadal dry weight(g). Gonadal dry weight was estimated by the percentage of humidity content of the gonad used for the calorimetric determination and the wet mass of the total of the gonads.

Two-way ANOVA was used to analyze the effect of time of experimentation and diet factors on color and gonadal indices, total carotene content, energy density and energy content. Simple effects were made in those factors on which significant differences were found. Also, when needed Tukey comparisons were made. In all cases, the assumptions of normality and homogeneity were tested using Kolmogorov - Smirnov and Levene, respectively (Sokal \& Rohlf, 1995). When necessary, logarithmic transformations were applied. Statistical analysis of data was performed by using Statistica 6.0.

\section{RESULTS}

Survival and growth rate: Survival for individuals feed with $\mathrm{LC}$ and $\mathrm{HC}$ diets was $100 \%$. All individuals used for the experiment accepted artificial food. There were not significant differences in the growth rate between artificial diets (ANOVA, $\mathrm{F}_{1,18}=, \mathrm{P}>0.05$ ).

Gonadal index: For the GI, the interaction between time and diet was significant (Twoway ANOVA, $\mathrm{F}_{2,53}=5.68, \mathrm{P}<0.01$ ) (Fig. 2). There were not significant differences in the GI at eight weeks of experimentation between

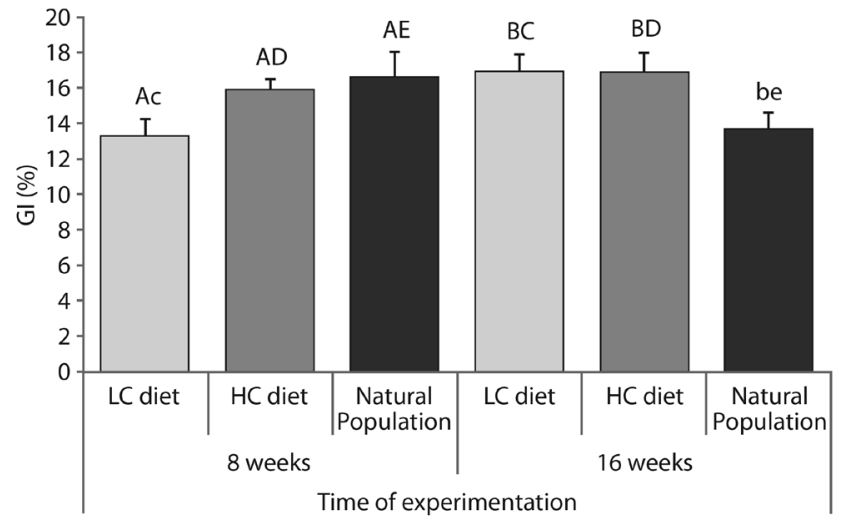

Fig. 2. Mean gonadal index (GI) (SEM) from experimental individuals of Loxechinus albus at eight and 16 weeks, fed with different diets. Statistical differences are indicated by pairs of capital and small letters.

Fig. 2. Índice Gonadal medio (GI) (ESM) de los individuos experimentales de Loxechinus albus a las ocho y 16 semanas de alimentación con diferentes dietas. Las diferencias estadísticas se indican con pares de letras mayúsculas y minúsculas. 
artificial diets (Simple Effects, $F_{2,26}=2.96$, $\mathrm{P}>0.05$ ). However, at 16 weeks there were significant differences in the GI between the artificial diets and the NP, where GI values from individuals fed with $\mathrm{LC}$ and $\mathrm{HC}$ diet were higher than those from the NP (LSD test, both $\mathrm{P}<0.05$ ). Yet, no significant differences were found between the GI of individuals fed with the LC and HC diets (LSD test, $\mathrm{P}>0.05$ ) at 16 weeks of experimentation. While GI values from the LC diet are significantly higher by the end of the experiment (Simple Effects, $\mathrm{F}_{1,17}=$ $6.62, \mathrm{P}<0.05)$, the ones from the NP descend (Simple Effects, $\mathrm{F}_{1,18}=4.59, \mathrm{P}<0.05$ ).

Histological analyses: From a total of 33 females, 99 microscopic fields were analyzed (three fields/female). Mean oocytes number (per microscopic field; Table 1) did not present a significant interaction between time and diet factors (Two-way ANOVA, $\mathrm{F}_{2,22}=2.70$, $\mathrm{P}>0.05)$. Also, mean oocytes number did not vary significantly through time of experimentation (ANOVA, $\mathrm{F}_{1,22}=1.99, \mathrm{P}>0.05$ ) nor between diets (ANOVA, $\mathrm{F}_{2,22}=0.48, \mathrm{P}>0.05$ ).

Mean oocytes diameter (per microscopic field; Table 1) did not present a significant interaction between time and diet factors (Twoway ANOVA, $\left.\mathrm{F}_{2,21}=3.22, \mathrm{P}>0.05\right)$. However, it did vary significantly between diets (ANOVA, $\left.\mathrm{F}_{2,21}=25.49, \mathrm{P}<0.0001\right)$. While, at eight weeks NP presented significantly higher values than LC only (LSD test, $\mathrm{P}<0.01$ ), at 16 weeks NP values differed significantly from both $\mathrm{LC}$ and $\mathrm{HC}$ values (LSD test, both $\mathrm{P}<0.0001$ ). Also, NP presented significant differences between times of experimentation (LSD test, $\mathrm{P}<0.01$ ) showing higher values at 16 weeks.

The percentage of gonadal area occupied by oocytes did not present a significant interaction between time and diet factors (Two-way ANOVA, $\mathrm{F}_{2,23}=0.08, \mathrm{P}>0.05$ ) (Table 1), but NP values did vary significantly from LC and $\mathrm{HC}$ diets (HSD test, both $\mathrm{P}<0.001$ ) for both times, presenting in both cases a higher gonadal area in the NP.

The frequency distribution of oocytes sizes did not vary between individuals fed with both artificial diets during the experiment. Meanwhile, in the NP oocyte sizes were displaced towards higher sizes and low frequencies during the experiment, reaching the highest sizes in 16 weeks (Fig. 3).

Different stages of gonadal development during the study period were observed. For females, five gonadal stages were present (Fig.4): growth (G), advanced growth

TABLE 1

Oocyte number, oocyte diameter $(\mu \mathrm{m})$ and percentage of gonadal area occupied by oocytes $(\%)$ in Loxechinus albus females at eight and 16 weeks, fed with different diets. Mean $\pm \mathrm{SD}$.

\section{CUADRO 1}

Número de oocitos, diámetro de oocitos $(\mu \mathrm{m})$ y porcentaje de área gonadal ocupada por oocitos (\%) en hembras de Loxechinus albus a las ocho y 16 semanas de alimentación con diferentes dietas. Media \pm DS

\begin{tabular}{clccccc}
\multirow{2}{*}{ Time } & \multicolumn{1}{c}{ Diet } & \multicolumn{2}{c}{ Oocyte number } & \multicolumn{2}{c}{ Oocyte diameter $(\mu \mathrm{m})$} & $\begin{array}{c}\text { Gonadal area occupied } \\
\text { by oocytes }(\%)\end{array}$ \\
\cline { 3 - 7 } 8 weeks & Low carotene & $18.83 \pm 8.33$ & $7.00-36.00$ & $38.05 \pm 6.63^{\mathrm{a}}$ & $27.84-50.18$ & $14.57 \pm 8.59^{\mathrm{f}}$ \\
& High carotene & $14.22 \pm 7.76$ & $4.00-30.00$ & $43.56 \pm 5.75$ & $34.29-51.75$ & $12.65 \pm 5.24^{\mathrm{f}}$ \\
& Nat. population & $21.67 \pm 7.21$ & $14.00-39.00$ & $51.51 \pm 3.33^{\mathrm{Ad}}$ & $44.84-56.54$ & $41.33 \pm 22.85^{\mathrm{F}}$ \\
\multirow{2}{*}{16 weeks } & Low carotene & $17.11 \pm 6.02$ & $9.00-32.00$ & $42.38 \pm 6.04^{\mathrm{b}}$ & $33.30-57.03$ & $16.37 \pm 8.64^{\mathrm{g}}$ \\
& High carotene & $16.83 \pm 5.15$ & $10.00-27.00$ & $41.19 \pm 7.53^{\mathrm{b}}$ & $27.84-51.82$ & $14.65 \pm 7.10^{\mathrm{g}}$ \\
& Nat. population & $10.29 \pm 8.36$ & $0.00-30.00$ & $63.60 \pm 5.81^{\mathrm{BD}}$ & $53.48-75.40$ & $47.04 \pm 6.94^{\mathrm{G}}$ \\
\hline
\end{tabular}

Statistical differences are indicated by pairs of capital and small letters. 

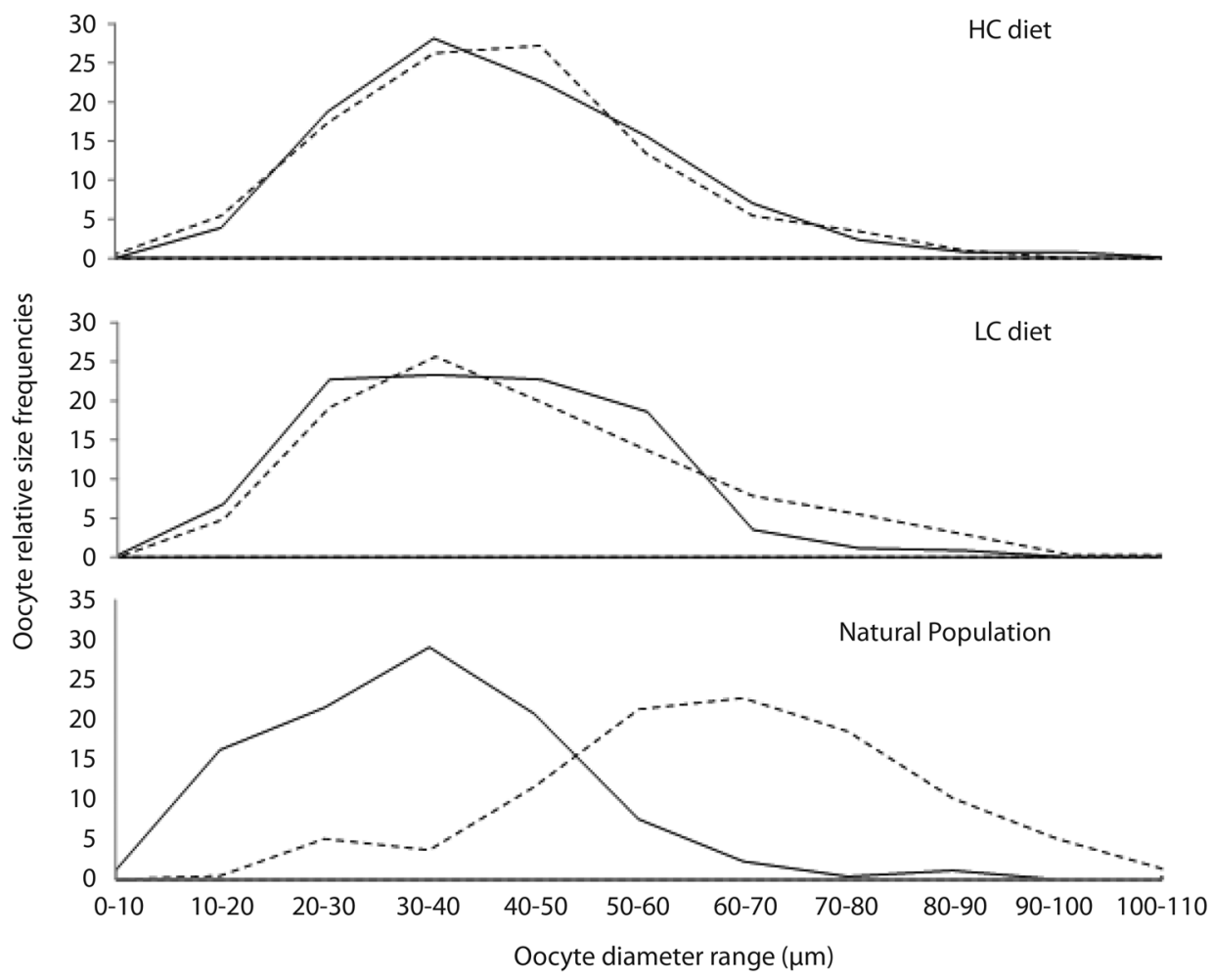

Fig. 3. Oocyte size frequencies of Loxechinus albus at eight (continuous line) and 16 (dotted line) weeks, fed with different diets.

Fig. 3. Frecuencia de tamaño de oocitos de Loxechinus albus a las ocho (línea continua) y 16 (línea punteada) semanas de alimentación con diferentes dietas.

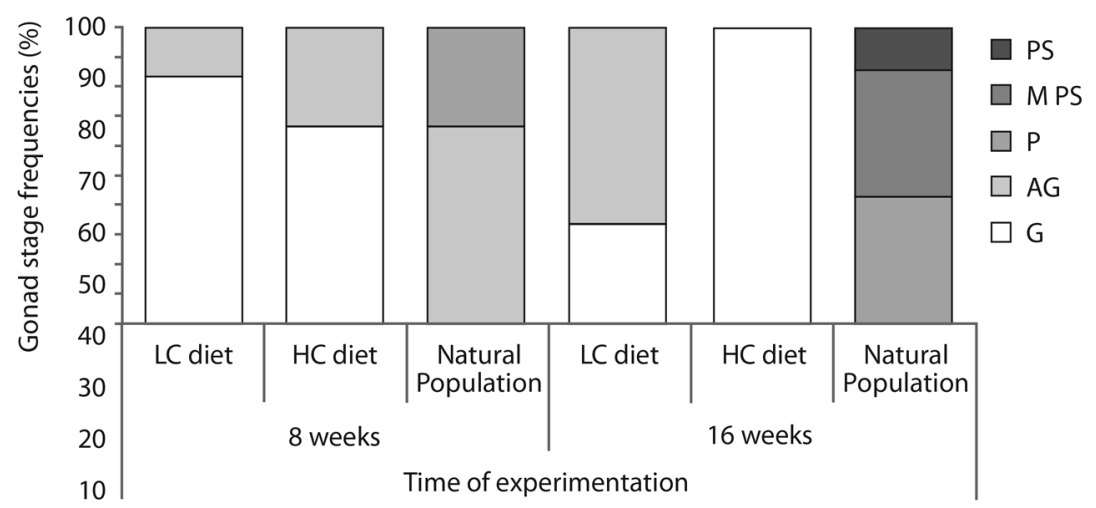

Fig. 4. Gonadal stage frequencies of Loxechinus albus females at eight and 16 weeks, fed with different diets. G: growing; AG: advanced growing; P: premature; M: mature; PS: partially spawned.

Fig. 4. Frecuencia de estadios gonadales de hembras de Loxechinus albus a las ocho y 16 semanas de alimentación con diferentes dietas. G: crecimiento; AG: crecimiento avanzado; P: pre maduro; M: maduro; PS: parcialmente desovado. 
(AG), premature $(\mathrm{P})$, mature $(\mathrm{M})$, partially spawned (PS).

After eight weeks of experimentation while females of the NP were in advanced growth stage $(67 \%)$ and premature stage (33\%), females in both treatments (LC and $\mathrm{HC})$ were in their majority still in growth stage ( $83 \%$ and $67 \%$, respectively) (Fig. 4). At 16 weeks, all females in the $\mathrm{HC}$ treatment were still in growth stage, likewise the majority of the females in the LC treatment $(67 \%)$. Meanwhile, the females in the NP were $43 \%$ in premature stage, $44 \%$ in mature stage, and $13 \%$ had partially spawned.

Color Index: For the color index (CI) (Fig. 5), the interaction between time and diet was significant (Two-way ANOVA, $\mathrm{F}_{2,54}=$ 5.31, $\mathrm{P}<0.01)$. Significant differences in the CI were found at eight weeks of experimentation (Simple Effects, $\mathrm{F}_{2,27}=4.40, \mathrm{P}<0.05$ ), where $\mathrm{CI}$ values from individuals fed with $\mathrm{HC}$ diet were higher than those fed with the LC diet (LSD test, $\mathrm{P}<0.01$ ) and from the NP (LSD test, $\mathrm{P}<0.05$ ). However, at 16 weeks of experimentation there were not significant differences in the CI among different diets or the NP (Simple Effects, $\left.\mathrm{F}_{2,27}=1.53, \mathrm{P}>0.05\right)$. Also, CI vary significantly between time of experimentation both in the $\mathrm{LC}$ and the $\mathrm{HC}$ diets, while $\mathrm{CI}$ values from the LC diet are higher by the end of the experiment (Simple Effects, $\mathrm{F}_{1,18}=$ 4.63, $\mathrm{P}<0.05$ ), the $\mathrm{CI}$ values from the $\mathrm{HC}$ diet descend (Simple Effects, $\mathrm{F}_{1,18}=5.90, \mathrm{P}<0.05$ ).

Total carotene content and calorimetric determinations: Total carotene content (TCC) presented a significant interaction between time and diet factors (Two-way ANOVA, $\mathrm{F}_{2}$, ${ }_{23}=4.45, \mathrm{P}<0.05$ ) (Fig. 6). There were not significant differences within time of experimentation (eight and 16 weeks) among diets (Simple Effects, $\mathrm{F}_{2,11}=3.07$ and $\mathrm{F}_{2,12}=2.76$, respectively, both $\mathrm{P}>0.05$ ). TCC values for $\mathrm{LC}$ diet were not significantly different between time of experimentation (Simple Effects, $\mathrm{F}_{1}$, $8=0.27, \mathrm{P}>0.05$ ), nor did values for $\mathrm{HC}$ diet (Simple Effects, $\mathrm{F}_{1,7}=0.44, \mathrm{P}>0.05$ ). However, TCC values for NP vary significantly between eight and 16 weeks (Simple Effects, $\mathrm{F}_{1,8}=$ $12.15, \mathrm{P}<0.01$ ), showing higher values by the end of the experiment.

For density and energetic content (ED and EC) (Table 2), the interaction between the factors time and diet was not significant (Twoway ANOVAs, $\mathrm{F}_{2,54}=2.30$ and $\mathrm{F}_{2,54}=2.81$,

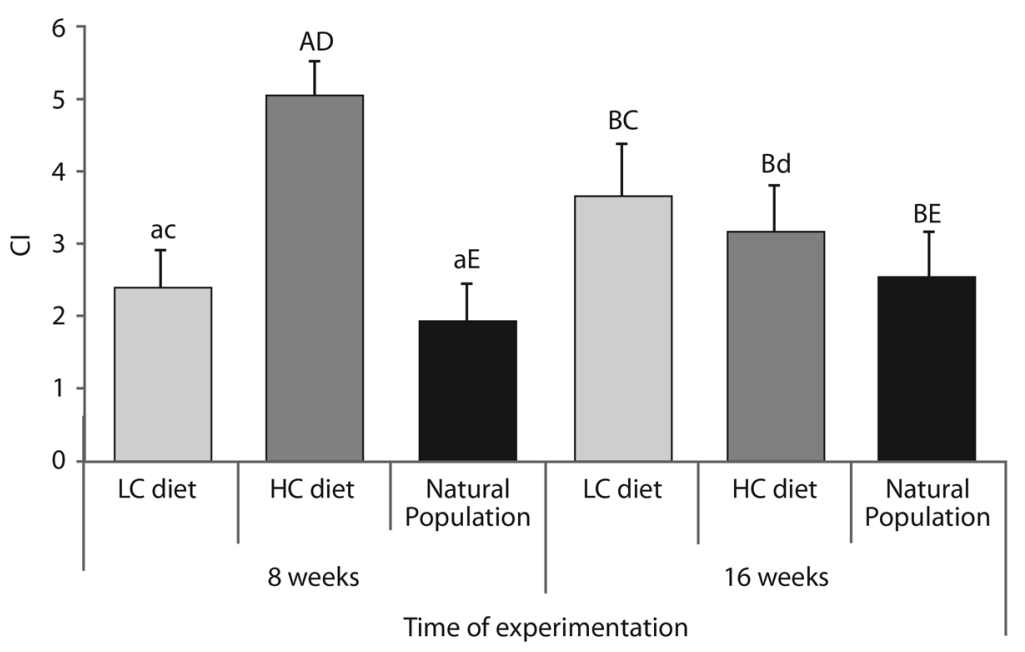

Fig. 5. Mean color index (CI) (SEM) from experimental individuals of Loxechinus albus at eight and 16 weeks, fed with different diets. Statistical differences are indicated by pairs of capital and small letters.

Fig. 5. Índice de color medio (CI) (ESM) de los individuos experimentales de Loxechinus albus a las ocho y 16 semanas de alimentación con diferentes dietas. Las diferencias estadísticas se indican con pares de letras mayúsculas y minúsculas. 
TABLE 2

Density and energetic content (ED and EC) in Loxechinus albus at eight and 16 weeks, fed with different diets. Mean \pm SD

\section{CUADRO 2}

Densidad y contenido energético (ED y EC) en Loxechinus albus a las ocho y 16 semanas de alimentación con diferentes dietas. Media \pm DS

\begin{tabular}{|c|c|c|c|}
\hline \multirow{2}{*}{ Time } & \multirow{2}{*}{ Diet } & DE KJ/gr(GH res.) & $\mathrm{CE}$ ( KJ total) \\
\hline & & Mean \pm SD & Mean \pm SD \\
\hline \multirow[t]{3}{*}{8 weeks } & Low carotene & $25.99 \pm 0.91$ & $169.06 \pm 89.91$ \\
\hline & High carotene & $25.27 \pm 0.91$ & $161.92 \pm 19.85$ \\
\hline & Nat. population & $26.45 \pm 1.28$ & $209.99 \pm 73.25$ \\
\hline \multirow[t]{3}{*}{16 weeks } & Low carotene & $26.23 \pm 1.38$ & $165.17 \pm 34.88$ \\
\hline & High carotene & $25.45 \pm 1.60$ & $164.30 \pm 41.22$ \\
\hline & Nat. population & $25.23 \pm 1.06$ & $146.44 \pm 36.65$ \\
\hline
\end{tabular}

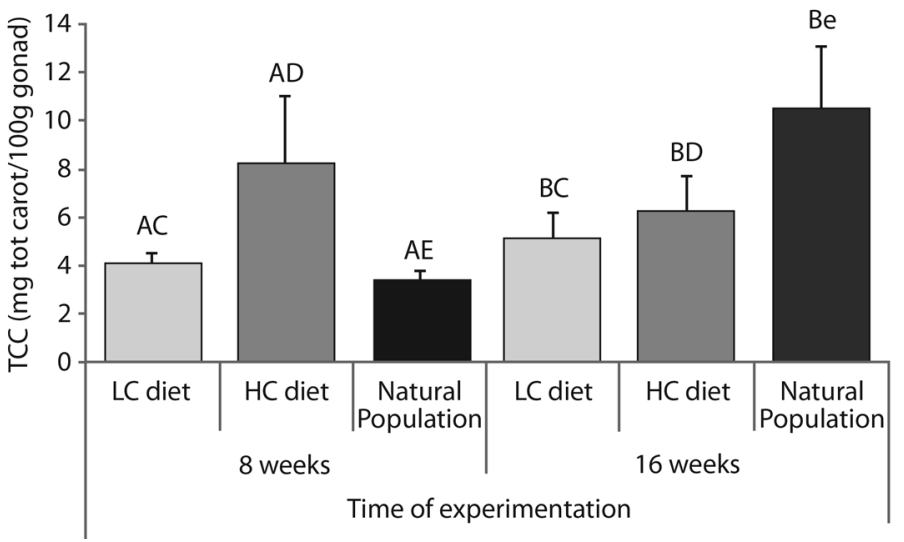

Fig. 6. Meant total carotene content (TCC) (SEM) from experimental individuals of Loxechinus albus at eight and 16 weeks, fed with different diets. Significant differences are indicated by pairs of capital and small letters.

Fig. 6. Contenido de caroteno total medio (TCC) (ESM) de los individuos experimentales de Loxechinus albus a las ocho y16 semanas de alimentación con diferentes dietas. Las diferencias estadísticas se indican con pares de letras mayúsculas y minúsculas.

respectively, both $\mathrm{P}>0.05)$. ED and $\mathrm{EC}$ did not present significant differences among different diets (ANOVAs, $\mathrm{F}_{2,54}=1.92$ and $\mathrm{F}_{2,54}=0.288$, respectively, both $\mathrm{P}>0.05)$ at eight and 16 weeks of experimentation (ANOVAs, $\mathrm{F}_{1,54}=$ 0.72 and $\mathrm{F}_{1,54}=1.91$, respectively, both $\mathrm{P}>0.05$ ).

\section{DISCUSSION}

Loxechinus albus is an appropriate species to be kept in captivity, as their mortality is very low, facilitating the realization of long-term experiences of gonadal improvement. L. albus survival recorded here was $100 \%$, while Lawrence (1997) obtained lower average values for that species (approximately 85\%). This difference in survival is probably due to better adaptation to captive conditions or greater food acceptance. Meidel and Scheibling (1999) and Kennedy et al. (2005) have also obtained high values of survival on experiences with Strongylocentrotus droebachiensis. The lack of differences in the growth rate between artificial diets can be explained by the fact that individuals captured for the experiment were adults of $70 \mathrm{~mm}$ diameter. Flores et al. (2010) conclude 
that growth rate in L. albus fits a linear model only at early ages (until 40-45 mm), while for Schuhbauer et al. (2010) L. albus growth rate fits the von Bertalanffy model. This suggest a clear decrease in growth velocity as size and age increase in L. albus (Gebauer \& Moreno, 1995). The same pattern occurs in Strongylocentrotus purpuratus (Gonor, 1972) and Strongylocentrotus franciscanus McBride (2004). As Hammer, Watts, Lawrence, Lawrence, and Desmond (2006) conclude, evaluation of growth in adult sea urchins is difficult to assess, particularly in studies of short duration, because weight gain and increases in test diameter are less obvious in adult sea urchins.

The dynamic of commercial markets is not usually synchronized with the life cycles of sea urchins, moreover harvest periods are too short so market demands off-season harvests (Vadas, Beal, Dowling, \& Fegley, 2000). A known method to overcome this discrepancy between the life cycles and market demand is to improve the gonads artificially. There is a lot of information available about experiences where gonad improvement has been achieved (Lawrence, 1997; McBride, 2004; Woods, James, Moss, Wright, \& Siikavuopio, 2008; Vadas et al., 2000). The gonadal improvement can be performed under laboratory conditions or in the field using either natural or artificial diets (Shpigel, McBride, Marciano, Ron, \& Ben-Amotz, 2005; Woods et al., 2008). Some studies suggest that gonads recently evacuated or at the beginning of gonadal growth, can be artificially improved under laboratory conditions (Klinger, Lawrence, \& Lawrence, 1997; Guillou et al., 2000; Vadas et al., 2000).

In this study, after 16 weeks of experimentation individuals fed with $\mathrm{LC}$ and $\mathrm{HC}$ diets had higher GI values compared with individuals form the NP, not recording a difference between artificial diets. So, independently of $\beta$-carotene concentration artificial diets increase the gonadal production. Lawrence (1997) found in the same species GI values similar to those obtained here (about 20 $\% \mathrm{GI}$ ), using artificial diets. LC and HC diets promoted gonadal growth as higher GI values were recorded before the release of gametes in relation to individuals who came from the natural population. Similar results were reported for several species of sea urchins (Lawrence, 1997; McBride, 2004; Shpigel et al., 2005). OteroVillaneuva, Kelly, and Burnell (2004) postulate that increased GI in Psammechinus miliaris fed with prepared diets was caused by the presence of easily absorbed dietary carbohydrate, on the other hand, Pearce et al. (2004) considered protein content as the main causative factor in elevated GI in Strongylocentrotus droebachiensis.

Reproductive stage can be an important market determinant. Sea urchin gonads are most valuable prior to and in the early stages of gametogenesis, when gonads are large but still firm in texture (Agatsuma, Sakai, \& Andrew, 2004). Individuals fed with artificial diets, had growth or advanced growth gonadal stages, while the NP presented stages of prematurity, maturity and partial spawning at the end of the experiment. Shpigel, Schlosser, BenAmotz, Lawrence, and Lawrence (2006) found similar results feeding Paracentrotus lividus with different artificial diets where the control individuals showed mature and recovering gametogenesis stages, while the ones fed with $\beta$-carotene diet showed a major percentage of growing gametogenesis stage. Also, Woods et al. (2008) found after eight weeks of feeding Evechinus chloroticus with artificial diet, that female sea urchins were at the growing stage, while wild female sea urchins were spread between partially spawned, spent, and recovering stage of reproduction. These results combined with the frequencies of the size distribution of oocytes (NP oocyte diameters shifted to higher values in less frequency) allow to conclude that in individuals fed with artificial diets gametogenesis seems to stop in relation to the NP, achieving the organoleptic characteristics of the gonads desired by the food market (Spirlet et al., 2000). Moreover, higher GI values at the end of the experiment for the artificial diets, could be achieved not because of greater amount of oocytes (number of oocytes among artificial diets and the NP did not vary significantly) but because of major 
presence of nutritive phagocytes (Unpublished data). The same was observed in Stongylocentrotus droebachiensis by Meidel and Scheibling (1999) and in Evechinus chloroticus by Woods et al. (2008) .

Even though the diameter of oocytes and the area occupied by oocytes was higher in the NP at 16 weeks of experimentation, the lower values of the GI can be explained by the presence of partially spawned individuals that descend the average GI. After eight weeks of experimentation, individuals fed with $\mathrm{HC}$ diet had a higher average value of CI compared with those from the field or the ones that received the LC diet. However, after 16 weeks the individuals fed with $\mathrm{HC}$ diet had a significant decrease of the CI values, while the individuals fed with the LC diet experienced a significant increase in the average value of $\mathrm{CI}$, reaching the same values that $\mathrm{HC}$ at 16 weeks. Hence optimal gonad coloration was reached at eight weeks of experimentation with the HC diet. This could be explained by dual function of carotenoids as antioxidants or pro-oxidants in response to its concentration so that at high carotenoid concentrations, the antioxidant effect of carotenoids decreases or may induce to pro-oxidant behavior (El-Agamey et al., 2004). This may result in brownish orange or dark brown gonads as the quantity of pro-oxidants increases. High CI values for artificial diets were obtained for other species by McBride (2004), Shpigel et al. (2006), among others.

There was no difference in the total carotene content (TCC) neither between artificial diets nor between times of experimentation. However, a non-significantly increase was observed at eight weeks with the $\mathrm{HC}$ diet that coincides with a CI increase. Though in the NP there was an increase in the TCC values at 16 weeks, this could be explained by other carotenoids incorporated in the natural diet. Shpigel et al. (2005) found in Paracentrotus lividus fed with deferent diets that total carotenoids were significantly higher when individuals were fed with marine algae naturally available. As improving the $\mathrm{CI}$ is not related only to the total carotene content (Robinson, Castell, \& Kennedy, 2002), it is necessary to explore which carotenoids are particularly involved in improving the color of the gonads of $L$. albus (Pérez et al., 2015). This study shows few variations in values of ED (between 25.23 and $26.45 \mathrm{~kJ} / \mathrm{g}$ AFDW) suggesting a stable biochemical composition, resulting close to energetic value of protein (Lucas, 1996). Despite the increase in gonadal size using $\mathrm{HC}$ and LC diets this did not translate into a change in ED and $\mathrm{EC}$ of the gonads. Based on previous investigations on L. albus, where seasonal changes in energy allocation to somatic and reproductive body components were studied (Pérez et al., 2008) and also energetic variations of the reproductive cycle (Pérez et al., 2010), it can be inferred that ED and EC values recorded here are associated with the reproductive stages from each experimental group. ED from the gonadal stages respond to the proportion of nutritive phagocytes with respect to gametes. The minimum value of EC in L. albus was recorded in mature stages when the nutritive phagocytes are scant, and maximum value was found in spawned and growing stages where gametes were strongly reduced in relation to nutritive phagocytes after spawning (Pérez et al., 2010). The nutritive phagocytes contain vacuoles with proteins, neutral mucopolysaccharides and lipids (Walker, Unuma, \& Lesser, 2007) explaining thus the high energetic values found in the spent gonads of L. albus.

Finally, it can be concluded that it is possible to improve the organoleptic characteristics of the gonads of $L$. albus by artificial diets enriched with $\beta$-carotene as size, color and turgidity improved (higher frequency of gonadal stages in advanced growth) in relation to the NP. Moreover, the optimal time to improve the organoleptic characteristics seems to be eight weeks with a high carotene artificial diet, where optimal gonad coloration was reached and GI values did not differed significantly from the ones achieved at the end of the experiment for the $\mathrm{LC} / \mathrm{HC}$ diet or the ones shown in the NP. This is translated on a lower cost by a reduced cultivation time. 


\section{ACKNOWLEDGMENT}

This study was supported by grants from CONICET (PIP 0128), ANPCyT (PICT 1270-2012 and PICT 1414-2014), Fundación Científica Felipe Fiorellino and University of Maimónides. Authors are grateful to the members of Laboratorio de Ecología, Fisiología y Evolución de Organismos Acuáticos (CADIC-CONICET) and particularly to D. Aureliano, M. Gutierrez and S. Rimbau for technical assistance.

\section{RESUMEN}

Las características organolépticas de los erizos de mar (tamaño y color, entre otros) pueden mejorarse mediante dietas artificiales. Loxechinus albus es considerado uno de los recursos económicamente más significativos de los sistemas litoral-bentónicos en el Océano Sur Pacífico desde Perú hasta Chile. El objetivo fue determinar los efectos de las dietas artificiales sobre las características organolépticos de las gónadas, la condición reproductiva, el crecimiento corporal y la supervivencia de L. albus. Se administraron dos dietas durante 16 semanas: una con bajo contenido de carotenos (LC) (alimento balanceado con $0,02 \%$ de $\beta$-caroteno) y otra con alto contenido de caroteno (HC) (alimento balanceado con $0,045 \%$ de $\beta$-caroteno). Como medida de la tasa de crecimiento, se midió el diámetro de caparazón de los erizos alimentados con dietas artificiales al principio y al final del experimento. En ambos casos, el tamaño (GI) y el color (CI) de las gónadas se registraron en diez individuos de cada tratamiento y diez en la población natural (NP). La densidad energética (ED), el contenido energético (EC) y los carotenos totales (TCC) se determinaron por calorimetría y espectrofotometría, respectivamente. Los cortes histológicos fueron examinados microscópicamente y el sexo fue identificado. Cada hembra fue asignada a una etapa gametogénica (condición reproductiva) y fueron determinados: número y diámetro de los oocitos, área gonadal ocupada por oocitos y frecuencias relativas de las etapas reproductivas. Al final del experimento fue posible lograr mayores valores de IG para ambas dietas artificiales en relación con el NP. La NP mostró mayor área gonadal ocupada por oocitos y mayor diámetro de oocitos a las 16 semanas $(\mathrm{P}<0,01)$. Además, los individuos alimentados con ambas dietas artificiales presentaron estadios gonadales de "crecimiento" y "crecimiento avanzado" (ambos tiempos), mientras que los individuos de la NP presentaron estadios de "premadurez", "madurez" y "desove parcial" en la semana 16. Los datos muestran el valor de CI fue mayor para la dieta $\mathrm{HC}$ a las ocho semanas $(\mathrm{P}<0,01)$. Además, los valores de TCC para el NP fueron significativamente mayores en la semana 16 ( $\mathrm{P}<0,01)$. L. albus es una especie apropiada para ser mantenida en cautiverio, ya que su mortalidad es muy baja, facilitando la realización de experiencias de mejoramiento gonadal a largo plazo. En este trabajo el tiempo óptimo para mejorar las características organolépticas es de ocho semanas con una dieta artificial con alto contenido de carotenos, ya que se alcanzó la coloración gonadal óptima y los valores GI no difirieron significativamente de los alcanzados al final del experimento para ambas dietas o los alcanzados por la NP. Esto se traduce en un menor costo, por un tiempo de cultivo reducido.

Palabras claves: Cultivo de equinodermos; $\beta$-caroteno; histología gonadal; mejoramiento gonadal; Canal Beagle.

\section{REFERENCES}

Agatsuma, Y., Sakai, Y., \& Andrew, N. L. (2004). Enhancement of Japan's sea urchin fisheries (M. Lawrence \& O. Guzman Eds.). Lancastetwor, USA: DESTec Publications Inc.

Andrew, N. L., Agatsuma, Y., Ballesteros, E., Bazhin, A. G., Creaser, E. P., Barnes, ... Xiaoqi, Z. (2002). Status and management of world sea urchin fisheries. - Oceanography and Marine Biology: An Annual Review 40, 343-425.

Beddingfield, S. D., \& McClintock, J. B. (1998). Differential survivorship, reproduction, growth and nutrient allocation in the regular echinoid Lytechinus variegatus (Lamarck) fed natural diets. Journal of Experimental Marine Biology and Ecology, 226, 195-215.

Borisovets, E. E., Zadorozhny, P. A., Kalinini, M. V., Lepskaya, N. V., \& Yakush, E. V. (2002). Change of major carotenoids in gonads of sea urchins (Strongylocentrotus intermedius and $S$. nudus) at maturation. Comparative Biochemistry and Physiology, 132, 779-790.

Brady, S. M., \& Scheibling, R. E. (2006). Changes in growth and reproduction of green sea urchins, Strongylocentrotus droebachiensis (Muller), during repopulation of the shallow subtidal zone after mass mortality. Journal of Experimental Marine Biology and Ecology, 335(2), 277-291.

Cossi, P. F., Boy, C., Giménez, J., \& Pérez, A. (2015). Reproductive biology and energy allocation of the sea star Cosmasterias lurida (Echinodermata: Asteroidea) from the Beagle Channel, Tierra del Fuego, Argentina. Polar Biology, 38(9), 1321-1333. doi: 10.1007/s00300-015-1696-x

El-Agamey, A., Lowe, G. M., McGarvey, D. J., Mortensen, A., Phillip, D. M., Truscott, T. G., \& Young, A. J. (2004). Carotenoid radical chemistry and antioxidant/pro-oxidant properties. Archives of Biochemistry and Biophysics, 430, 37-48. doi: 10.1016/j. abb.2004.03.007 
Fernandez, C. M., \& Boudouresque, C. F. (2000). Nutrition of the sea urchin Paracentrotus lividus (Echinodermata:Echinoidea) fed different artificial food. Marine Ecology Progress Series, 204, 131-141.

Flores, L., Ernst, B., \& Parma, A. M. (2010). Growth pattern of the sea urchin, Loxechinus albus (Molina, 1782) in southern Chile: evaluation of growth models. Marine Biology, 157, 967-977.

Foster, M. C., Byrnes, J. E. K., \& Reed, D. C. (2015). Effects of five southern California macroalgal diets on consumption, growth, and gonad weight, in the purple sea urchin Strongylocentrotus purpuratus. PeerJ. doi: https://doi.org/10.7717/peerj.719

Fuji, A. (1967). Ecological studies on the growth and food consumption of Japanese common littoral sea urchin, Strongylocentrotus intermedius (A. Agassiz). Memoirs of Faculty of Fisheries Hokkaido University, $15,83-160$.

Garrido, C. L., \& Barber, B. J. (2001). Effects of temperature and food ration on gonad growth and oogenesis of the green sea urchin, Strongylocentrotus droebachiensis. Marine Biology, 138, 447-456.

Gebauer, P., \& Moreno, C. A. (1995). Experimental validation of the growth rings of Loxechinus albus (Molina,1782) in southern Chile (Echinodermata: Echinoidea). Ficheries Research, 21, 423-435.

Gonor, J. J. (1972). Gonad growth in the sea urchin, Strongylocentrotus purpuratus (stimpson) (echinodermata: Echinoidea) and the assumptions of gonad index methods. Journal of Experimental Marine Biology and Ecology, 10, 89403.

Guillou, M., Lumingas, L. J., \& Michel, C. (2000). The effect of feeding or starvation on resource allocation to body components during the reproductive cycle of the sea urchin Sphaerechinus granularis (Lamarck). Journal of Experimental Marine Biology and Ecology, 245, 183-196.

Guisado, C., \& Castilla, J. C. (1987). Historia de vida, reproducción y avances en el cultivo del erizo comestible chileno Loxechinus albus (Molina, 1782) (Echinoidea: Echinidae) (P. Arana Ed.). Valparaíso: Esc. Ciencias del Mar, UCV.

Hammer, H., Watts, S., Lawrence, A., Lawrence, J., \& Desmond, R. (2006). The effect of dietary protein on consumption, survival, growth and production of the sea urchin Lytechinus variegatus. Aquaculture, 254(1-4), 483-495. doi: 10.1016/j.aquaculture.2005.10.047

Klinger, T. S., Lawrence, J. M., \& Lawrence, A. L. (1997). Gonad and somatic production of Strongylocentrotus droebanchiensis fed manufactured feeds. . Bulletin of Aquacult Association Canadian, 97, 35-37.

Lawrence, J. M. (1997). Enhancement of Gonad Production in the Sea Urchin Loxechinus albus in Chile Fed
Extruded Feeds. Journal of the World Aquaculture Society 28 .

Lucas, A. (1996). Energetics of aquatic animals. Taylor and Francis Press.

McBeth, J. W. (1972). Carotenoids from nudibranchs. Comparative Biochemistry and Physiology, 41, 55-68.

McBride, S. (2004). Comparison of gonad quality factors: color, hardness and resilience, of Strongylocentrotus franciscanus between sea urchins fed prepared feed or algal diets and sea urchins harvested from the Northern California fishery. Aquaculture, 233(1-4), 405-422. doi: 10.1016/j.aquaculture.2003.10.014

Meidel, S. K., \& Scheibling, R. E. (1999). Effects of food type and ration on reproductive maturation and growth of the sea urchin Strongylocentrotus droebachiensis. . Marine Biology, 134, 155 - 166.

Olave, S., \& Busto, E. (2001). The Effect of Size and Diet on Gonad Production by the Chilean Sea Urchin Loxechinus albus. Journal of the World Aquaculture Society 32(2).

Otero-Villaneuva, M., Kelly, M. S., \& Burnell, G. (2004). How diet influences energy partitioning in the regular echinoid Psammechinus miliaris; constructing an energy budget. Journal of Experimental Marine Biology and Ecology, 304, 159-181.

Pearce, C. M., Daggett, T. L., \& Robinson, S. M. C. (2004). Effect of urchin size and diet on gonad yield and quality in the green sea urchin (Strongylocentrotus droebachiensis). Aquaculture, 233(1-4), 337-367. doi: 10.1016/j.aquaculture.2003.09.027

Pérez, A., Boy, C., Morriconi, E., \& Calvo, J. (2009). Reproductive cycle and reproductive output of the sea urchin Loxechinus albus (Echinodermata: Echinoidea) from Beagle Channel, Tierra del Fuego, Argentina. Polar Biology, 33(3), 271-280. doi: 10.1007/ s00300-009-0702-6

Pérez, A., Boy, C., Morriconi, E., \& Calvo, J. (2010). Reproductive cycle and reproductive output of the sea urchin Loxechinus albus (Echinodermata: Echinoidea) from Beagle Channel, Tierra del Fuego, Argentina. Polar Biology, 33, 271-280.

Pérez, A., Lattuca, M. E., Fraysse, C., \& Malanga, G. (2015). Effect of dietary carotenoids on lipoperoxidation in mature sea urchins Loxechinus albus (Echinodermata: Echinoidea). Indian Journal of Geo-Marine Sciences, 44(3), 354-363.

Pérez, A., Malanga, G., \& Puntarulo, S. (2011). Reproductive condition associate to changes in the liposoluble antioxidant capacity and the damage to lipids in the sea urchins Loxechinus albus (Echinodermata: Echinoidea). Revista Ciencias Marinas y Costeras, 3, 183-194. 
Pérez, A., Morriconi, E., Boy, C., \& Calvo, J. (2008). Seasonal changes in energy allocation to somatic and reproductive body components of the common cold temperature sea urchin Loxechinus albus in a SubAntarctic environmet. Polar Biology, 31, 443-449.

Plank, L. R., Lawrence, J. M., Lawrence, A., \& Olvera, R. M. (2002). The effect of dietary carotenoids on gonad production and carotenoid profile in the sea urchin Lytechinus variegatus. Journal Of The World Aquaculture Society, 33, 127-137.

Robinson, S. M. C., Castell, J. D., \& Kennedy, E. J. (2002). Developing suitable colour in the gonads of cult ured green sea urchins (Strongylocentrotus droebachiensis). Aquaculture 206, 289-303.

Russell, M. P. (1998). Resource allocation plasticity in sea urchins: rapid, diet induced, phenotypic changes in the green sea urchin, Strongylocentrotus droebachiensis (Muller). Journal of Experimental Marine Biology and Ecology, 220, 1-14.

Schuhbauer, A., Brickle, P., \& Arkhipkin, A. (2010). Growth and reproduction of Loxechinus albus (Echinodermata: Echinoidea) at the southerly peripheries of their species range, Falkland Islands (South Atlantic). Marine Biology, 157, 1837-1847.

Shpigel, M., McBride, S., Marciano, S., Ron, S., \& BenAmotz, A. (2005). Improving gonad colour and somatic index in the European sea urchin Paracentrotus lividus. Aquaculture, 245(1-4), 101-109. doi: 10.1016/j.aquaculture.2004.11.043

Shpigel, M., Schlosser, S. C., Ben-Amotz, A., Lawrence, A. L., \& Lawrence, J. M. (2006). Effects of dietary carotenoid on the gut and the gonad of the sea urchin Paracentrotus lividus. Aquaculture, 261(4), 12691280. doi: 10.1016/j.aquaculture.2006.08.029

Siikavuopio, S. I., Mortensen, A., Dale, T., \& Foss, A. (2007). Effects of carbon dioxide exposure on feed intake and gonad growth in green sea urchin, Strongylocentrotus droebachiensis. Aquaculture, 266(1-4), 97-101. doi: 10.1016/j.aquaculture.2007.02.044

Sokal, R. R., \& Rohlf, J. (1995). Statistical tables: Macmillan

Spirlet, C., Grosjean, P., \& Jangoux, M. (2000). Optimization of gonad growth by manipulation of temperature and photoperiod in cultivated sea urchins, Paracentrotus lividus (Lamarck) (Echinodermata). Aquaculture, 185, 85-99.

Vadas, R. L., Beal, B., Dowling, T., \& Fegley, J. C. ( 2000). Experimental field tests of natural algal diets on gonad index and quality in the green sea urchin, Strongylocentrotus droebachiensis: a case for rapid summer production in post-spawned animals. Aquaculture 182, 115-135.

Walker, C. W., Unuma, T., \& Lesser, M. P. (2007). Gametogenesis and reproduction of sea urchins (J. M. Lawrence Ed. 2nd ed.). Ámsterdam: Elsevier.

Woods, C. M. C., James, P. J., Moss, G. A., Wright, J., \& Siikavuopio, S. (2008). A comparison of the effect of urchin size and diet on gonad yield and quality in the sea urchin Evechinus chloroticus Valenciennes. Aquaculture, 16, 49-68. doi: 10.1007/s10499-007-9124-z 